\title{
Perancangan Video Edukasi Sejarah Daerah Kota Tua Gresik untuk Meningkatkan Kesadaran Sejarah Masyarakat di Kota Gresik
}

\author{
Armand Firdhaus dan Nugrahardi Ramadhani \\ Departemen Desain Produk Industri, Fakultas Arsitektur, Desain dan Perancanaan, \\ Institut Teknologi Sepuluh Nopember (ITS) \\ e-mail: dhanisancok@ its.ac.id
}

\begin{abstract}
Abstrak-Kabupaten Gresik merupakan kota yang memiliki nilai kebudayaan dan sejarah dari berbagai objek maupun kegiatan. Salah satunya adalah Daerah Kota tua yang merupakan kawasan yang menjadi peninggalan bangunan bangunan tua yang berdiri sejak zaman kolonial Belanda. Namun, rendahnya tingkat pengetahuan terhadap sejarah Daerah Kota Tua Gresik, oleh masyarakat Gresik, membuat kepedulian terhadap daerah tersebut rendah. Sehingga dibutuhkan media untuk meningkatkan kesadaran sejarah terhadap masyarakat di kota Gresik. Penelitian ini mengkaji tentang peristiwa sejarah dan detail bangunan yang ada di Daerah Kota Tua untuk dijadikan sebagai informasi untuk disampaikan kepada masyarakat. Penelitian ini dibagi menjadi 2 tahap, yaitu mengkaji dasar judul penelitian tersebut dan konten yang akan ditampilkan. Sumber data yang diperoleh melalui bukti tertulis, wawancara mendalam dengan saksi sejarah dari Daerah Kota Tua Gresik dan Dinas Pariwisata Kabupaten Gresik, observasi, kuisioner yang disebar ke masyarakat kota gresik dan secara daring. Hasil luaran dari penelitian ini, berupa video edukasi sejarah Daerah Kota Tua Gresik dengan konsep "Jelajah Gresik - Kota Tua". Untuk seri ini terdiri 5-episode yang disesuaikan dengan zona etnisitas yang ada. Hasil luaran ini memberikan informasi asal usul terbentuknya tiap zona, detail dan ciri bangunan, dan peristiwa sejarah yang dapat menjadi referensi dan tahap awal untuk meningkatkan kesadaran sejarah.
\end{abstract}

Kata Kunci-Daerah Kota Tua Gresik, Video Edukasi, Kesadaran Sejarah.

\section{PENDAHULUAN}

$\mathrm{K}$ OTA Gresik merupakan daerah perkotaan yang menjadi saksi sejarah pada peristiwa tertentu. Salah satunya kawasan kota tua, dibuktikan dengan bangunan bangunan tua yang tersisa di pusat kabupaten Gresik. Bangunan - bangunan tua ini memiliki gaya arsitektur yang bermacam - macam, yaitu Belanda, Arab, Cina dan gaya lokal dari kota Gresik. Daerah bangunan tua tersebut disebut Daerah Kota Tua Gresik.

Menurut Oemar Zainuddin, beliau adalah pengelola Kampong Kemasan, lokasi kota tua yang ada di Gresik dibagi menjadi 5 zona etnisitas yaitu Kampung Arab Melayu, Kampung Pecinan, Pribumi, Area Kolonial Belanda, dan Kampung Peranakan [1]. Setiap Kampung tersebut memiliki cerita peristiwa sejarah dan ciri khas pada gaya bangunannya.

Informasi kesejarahan disampaikan melalui kegiatan di tiap zona, contohnya adalah Kampung Kemasan. Kegiatan yang dilakukan oleh wisatawan, seperti siswa hingga peneliti, di kawasan tersebut adalah mempelajari peristiwa sejarah yang ada [2].

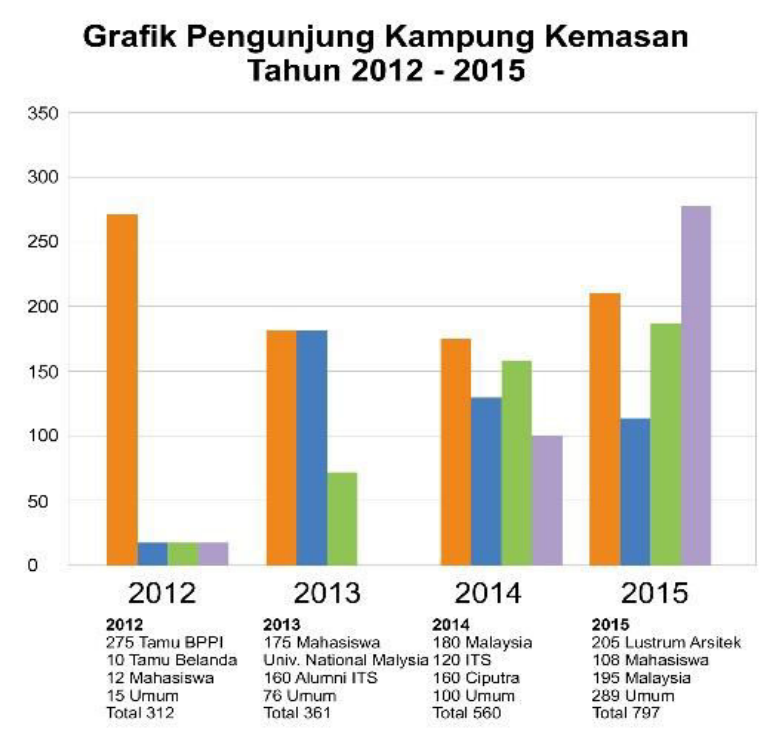

Gambar 1. Grafik Pengunjung Kampung Kemasan tahun 2012 - 2015.

Selain itu, Penyampaian informasi sejarah Daerah Kota Tua Gresik juga disampaikan melalui suatu acara, yaitu "Gresik Djaloe". Acara ini diselenggarakan dalam rangka menceritakan kembali kehiduan masyarakat Gresik jaman dulu dengan berbagai nilai/ produk seni budaya, sosial, dan keagamaanya. Tujuannya untuk meningkatkan kepekaan masyarakat terhadap sejarah dan bangunan di Kota Tua dan membuat masyarakat memiliki usaha baru untuk menunjang daya tarik wisata Daerah Kota Tua Gresik.

Namun, acara ini dianggap gagal oleh Dinas Pariwisata dan diberhentikan pada tahun 2016, dikarenakan indikator keberhasilannya tidak tercapai karena jumlah UKM yang terlibat hanya 6 UKM saja [3].

Selain itu, diawal tahun 2017 siswa SMA saat ini mulai diberi pembelajaran tentang kota Gresik, seperti peristiwa sejarah, dan cerita rakyat yang ada. Dengan siswa diberi tugas untuk mencari informasi tentang peristiwa sejarah melalui buku atau wawancara langsung dengan budayawan dan pembuktian secara ilmiah pada cerita rakyat yang ada.

Dari fenomena tersebut, dibutuhkan media informasi untuk memberikan pengetahuan secara umum yang menarik tentang sejarah Daerah Kota Tua Gresik.

Jika membahas media informasi yang komunikatif, maka media audio visual yang lebih cepat diterima karena disampaikan, melalui penglihatan dan pendengaran audiens. Untuk lebih spesisifik, media audiovisual berupa video edukasi yang digunakan. Diharapkan video edukasi ini dapat meningkatkan pengetahuan audiens dan meningkatnya kepeduliannya terhadap Daerah Kota Tua Gresik. 


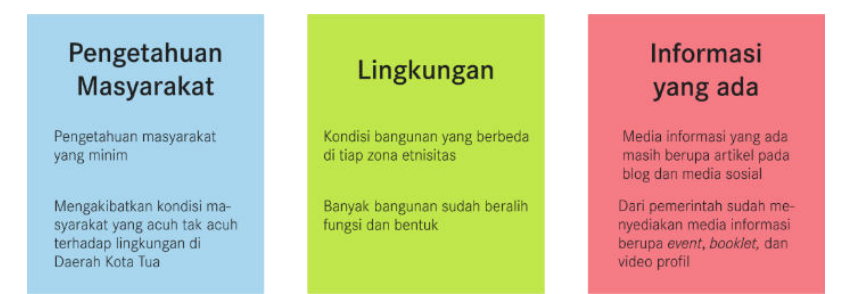

Gambar 1. Affinity diagram.

Sumber : Firdhaus 2016

\section{STUDI ACUAN}

\section{A. Tinjauan Kesadaran Sejarah}

Kesadaran sejarah atau historical consciousness adalah hasil pemikiran dan penghayatan seseorang terhadap peristiwa masa lalu, yang berdampak bagi masa depan. Kesadaran sejarah meliputi [4]:

1. pengetahuan tentang fakta sejarah,

2. pengisian alam pikiran dengan logika

3. peningkatan kearifan dan kebijaksanaan hati

nurani untuk bercermin pada pengalaman masa lalu.

Kesadaran sejarah dapat dicapai melalui pemahaman kesejarahan sesuai tingkat perkembangan, seperti berkunjung ke museum atau melihat video sejarah dan terampi berpikir dan menganalisa kesejarahan., seperti berpikir kronologis pada runtutan garis waktu peristiwa sejarah dan menyelaraskan dengan bukti yang ada.

Untuk mengenalkan sejarah Daerah Kota Tua Gresik ke masyarakat Gresik, tahap yang akan diberikan oleh masyarakat Gresik yaitu Berpikir Kronologis dan Komprehensif. Dimana masyarakat diberikan bukti sejarah yang ada melalui media dan perbandingan peristiwa sejarah saat ini. Kedua tahap ini menjadi dasar untuk meningkatkan kesadaran sejarah terhadap Daerah Kota Tua Gresik.

\section{B. Tinjauan Video Edukasi}

Video edukasi merupakan penyampaian informasi pembelajaran melalui teknologi dan indra penglihatan dan pendengaran [5]. Beberapa hal yang dipertimbangkan untuk membuat video edukasi, seperti menggunakan sumber sejarah yang jelas dan terpercaya, durasi penyampaian yang dibuat pendek dan to the point, ada pesan yang disampaikan selain pengetahuan agar audiens bisa merefleksikan pada dirinya, dan tetap berdasar dengan tujuan video, yaitu sebagai hiburan.

\section{Tinjauan Audio Visual}

Media Audio visual adalah jenis media yang mengandung unsur suara dan unsur gambar. Contohnya video. Penyampaian media ini dianggap lebih baik dan menarik.

Audio visual dapat menjadi media dokumentasi dan dapat juga menjadi media komunikasi [6]. Sebagai media dokumentasi tujuan yang lebih utama adalah mendapatkan fakta dari suatu peristiwa. Sedangkan sebagai media komunikasi, sebuah produk audio visual melibatkan lebih banyak elemen media dan lebih membutuhkan perencanaan agar dapat mengko-munikasikan sesuatu. Film cerita, iklan, media pembelajaran adalah contoh media audio visual yang lebih menonjolkan fungsi komunikasi. Media dokumentasi sering menjadi salah satu elemen dari media komunikasi. Karena melibatkan banyak elemen media, maka produk audio visual yang diperuntukkan sebagai media komunikasi kini sering disebut sebagai multi-media. Karakteristik Audio Visual antara lain [7]:
1) Bersifat linear

2) Menyajikan visual yang dinamis

3) Digunakan dengan cara yang ditentukan sebelum merancang

4) Merupakan representasi fisik dari sebuah gagasan

\section{METODOLOGI RISET DESAIN}

Untuk menunjang judul perancangan yang diambil, maka dilakukan riset data. Proses ini dibagi menjadi 2 tahap, yaitu tahap pra riset dan riset.

\section{A. Pra Riset}

Tahap ini merupakan tahap perencanaan untuk menentukan judul dan topik yang dibahas.. Perolehan data melalui :

1) Metode kumulatif melalui Badan Pusat Statistika Kabupaten Gresik

2) Metode kumulatif melalui Badan Penelitian Daerah Kabupaten Gresik

3) Metode wawancara melalui Dinas Pariwisata Kabupate Gresik

4) Studi pustaka terhadap literatur sejarah Gresik

5) Studi eksisting dan komparator

6) Metode observasi pada kegiatan yang dilakukan di kawasan tersebut.

\section{B. $\quad$ Riset}

Tahap ini merupakan tahap perencanaan untuk menentukan judul dan topik yang dibahas.. Perolehan data melalui :

1) Metode wawancara pada tiap pengelola dari 5 zona etnisitas

2) Observasi pada tiap zona etnisitas

3) Metode wawancara melalui Dinas Pariwisata Kabupaten Gresik

4) Studi Pustaka terhadap buku pelajaran siswa SMA kelas 10 dan peristiwa sejarah di Kota Tua Gresik

5) Studi Etnogreafi terhadap audiens dan masyarakat Kota Tua Gresik

6) Metode kuisioner untuk post test video edukasi

\section{Analisa Hasil Penelitian}

Berdasarkan hasil penelitian yang telah diuraikan, masalah yang ada kemudian dikelompokkan berdasarkan affinity diagram. Masalah tersebut dibagi menjadi pengetahuan masyarakat, lingkungan, informasi yang ada.

Dari ketiga aspek pada Gambar 1, permasalahan utama yang menjadi domino effect bagi masalah lain yaitu masyarakat kota Gresik itu sendiri. Karena tingkat pengetahuan sejarah Daerah Kota Tua Gresik yang rendah, kepekaan mereka terhadap bangunan dan lingkungan yang ada di Daerah Kota Tua Gresik juga rendah. Sehingga saat pemerintah ingin membenahi daerah tersebut, dukungan dari masyarakat yang dibutuhkan, seperti menunjang sarana dan prasarana. Karena rendahnya pengetahuan sejarah Daerah Kota Tua Gresik, masyarakat enggan untuk mengurus sertifikat kepemilikan agar bangunan tersebut bisa menjadi bangunan cagar budaya.

\section{Formulasi Kebutuhan}

Dari masalah yang telah dianalisa dan diuraikan, banyak hal yang dibutuhkan untuk menyelesaikan masalah domino 
effect tersebut. Dengan memberikan pengetahuan sejarah Daerah Kota Tua Gresik secara umum , tapi tidak terlalu mendetail. Pengetahuan yang diberikan berdasarkan apa yang mereka lihat sehari - hari, seperti pengetahuan tentang bangunan Gajah Mungkur, Kampung Kemasan, Klenteng, dan lain sebagainya. Pengetahuan umum yang diberikan, diharapkan mampu menggugah keinginan masyarakat untuk tahu lebih dalam tentang sejarah Daerah Kota Tua Gresik. Sehingga kepekaan mereka dapat dibangun perlahan lahan.

Gaya bahasa yang mudah dipahami masyarakat dan pengambilan gambar yang menarik akan memudahkan masyarakat untuk memahami sejarah Daerah Kota Tua Gresik. Perbandingan gambar pada zaman dulu dengan zaman sekarang membuat konten yang disampaikan lebih menarik. Sehingga saat pengetahuan sejarah telah disampaikan ke masyarakat, diharapkan kepekaan mereka terhadap Daerah Kota Tua Gresik juga ikut tumbuh.

\section{KONSEP DESAIN}

Output dari perancangan ini adalah sebuah video edukasi yang berisi konten berupa informasi secara umum mengenai sejarah Daerah Kota Tua Gresik. Informasi yang disampaikan adalah narasi berupa informasi latar belakang berdirinya kampung, peristiwa sejarah yang pernah terjadi, dan ciri keunikan yang ada di tiap zona etnisitas. Dengan berdurasi sekitar \pm 5 menit pada tiap zona etnisitasnya.

\section{A. What To Say}

Berdasarkan identifikasi masalah yang ada, maka dapat ditentukan what to say yaitu mengenalkan tentang Kota Tua Gresik dengan memberikan informasi tentang peristiwa sejarah dan ciri bangunan pada masyarakat, juga disesuaikan dengan usia pada jenjang SMP - SMA.

\section{B. How To Say}

Dari what to say yang sudah dibuat, maka dibuat how to say yaitu menyampaikan informasi tentang Kota Tua Gresik deengan konsep bertanya dan bercerita. Disajikan dengan gambaran ciri bangunan dan foto peristiwa sejarah. Ditambah dengan elemen naratif berupa penyampaian informasi deengan gaya bahasa yang disesuaikan dengan audiens.

\section{Keyword}

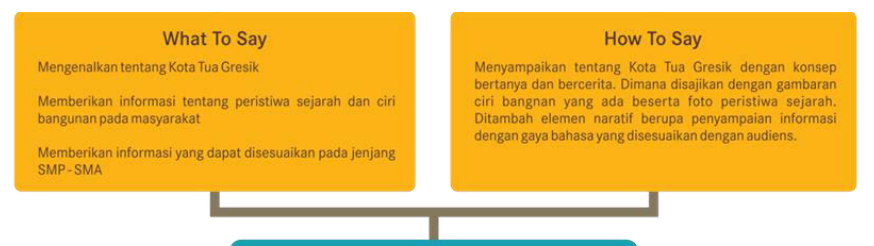

\section{JELAJAH GRESIK}

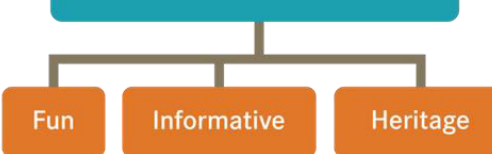

Gambar 3 Bagan proses menuju keyword

Sumber : Firdhaus 2016

Konsep dari video ini diambil dari keyword yang muncul dari hasil analisa, yaitu "Jelajah Gresik", dimana audiens ditampilkan objek dan daya tarik wisata, seperti wisata bersejarah, wisata religi, wisata hiburan, dan sebagainya. Konsep yang disampaikan yaitu fun, dimana narasi yang disampaikan menggunakan gaya bahasa yang santai dan membangun suasana senang. Informatif, dimana narasi yang disampaikan sesuai fakta yang ada. Dan Heritage, dimana tema yang diusung merupakan unsur budaya pada masing masing objek wisata.

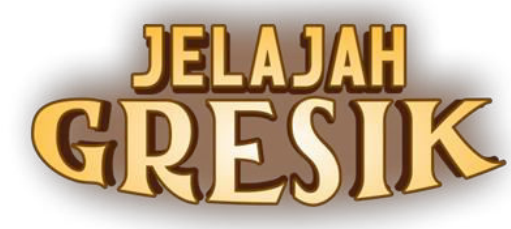

Gambar 4 Logo Jelajah Gresik

Sumber : Firdhaus 2016

"Jelajah Gresik" memiliki turunan seri yang akan dibuat, seperti "Jelajah Gresik - Kota Tua" dimana episode ini membahas seputar fakta tentang kota tua yang ada di Kabupaten Gresik. Di dalam episode kota tua ini, dibagi menjadi 5 episode berdasarkan zona etnisitas yang ada. Dari tiap zona etnisitas akan memiliki logo yang berbeda satu sama lain.

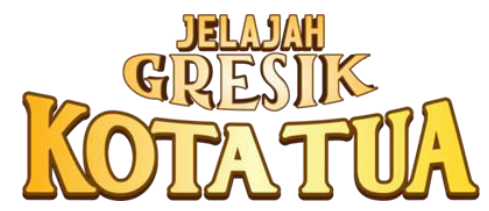

Gambar 5 Logo Jelajah Gresik - Kota Tua Sumber : Firdhaus 2016

\section{A. Konsep Alur Cerita Dan Pembabakan}

Pada video edukasi yang dibuat, terdapat 4 babak yaitu Bumper, Prolog, Konten dan Closing. Sedangkan untuk penyampaian konten dibagi menjadi 5 bagian yaitu membahas Kota Tua secara umum, arti cagar budaya, detail dan ciri bangunan, peristiwa sejarah, dan korelasi pada masa kini.

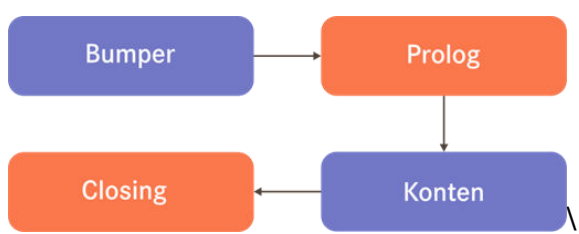

Gambar 6 Bagan Pembabakan pada video

Sumber : Firdhaus 2016

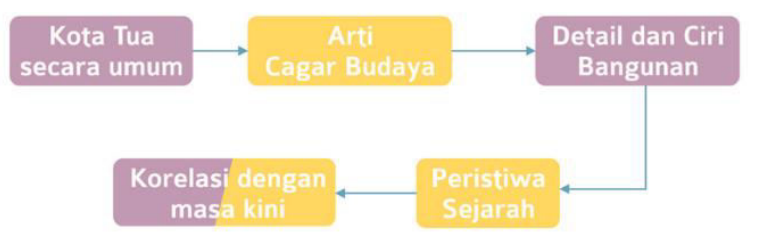

Gambar 7. Bagan pembagian konten

Sumber : Firdhaus 2016

\section{B. Kriteria Desain}

1) Judul: Jelajah Gresik Kota Tua 
2) Ide : Menelusuri Daerah Kota Tua Gresik yang kini tidak diacuhkan oleh masyarakat Gresik

3) Sinopsis : Perjalanan sepasang muda - mudi yang ingin mengetahui sejarah Daerah Kota Tua Gresik lebih dalam. Dia hanya mengetahui sejarahnya secara umum, bukan dari tiap zona etnisitas yang ada. Perjalanan dimulai dari berkeliling melihat bangunan di kota tua. Kemudian dilanjut menuju salah satu kampung (kampung yang berbeda pada tiap episodenya)

4) Bentuk : Naratif dan deskriptif

5) Elemen : Suasana Daerah Kota Tua Gresik beserta arsi-tektural bangunan yang ada di daerah tersebut, interview terhadap sejarahwan terkait.

6) Durasi :Tiap episode $4-6$ menit

\section{Produksi Film}

Setelah melewati proses pembuatan konsep, pembuatan film pun melewati masa produksi. Masa ini membutukan waktu dan memerlukan perencanaan yang matang, yaitu dengan membuat storyboard dan schedule untuk dilaksanakan produksi.

Masa produksi melalui tahapan perencanaan storyboard sebagai acuan dalam pengambilan gambar, talent yang ditampilkan sebagai pembawa acara dan komunikator , setting tempat,untuk disesuaikan dengan konsep video edukasi, penggunaan alat produksi seperti kamera dan stabilizer, penggunaan cahaya yang cukup, dan penggunaan sinematografi pada video.

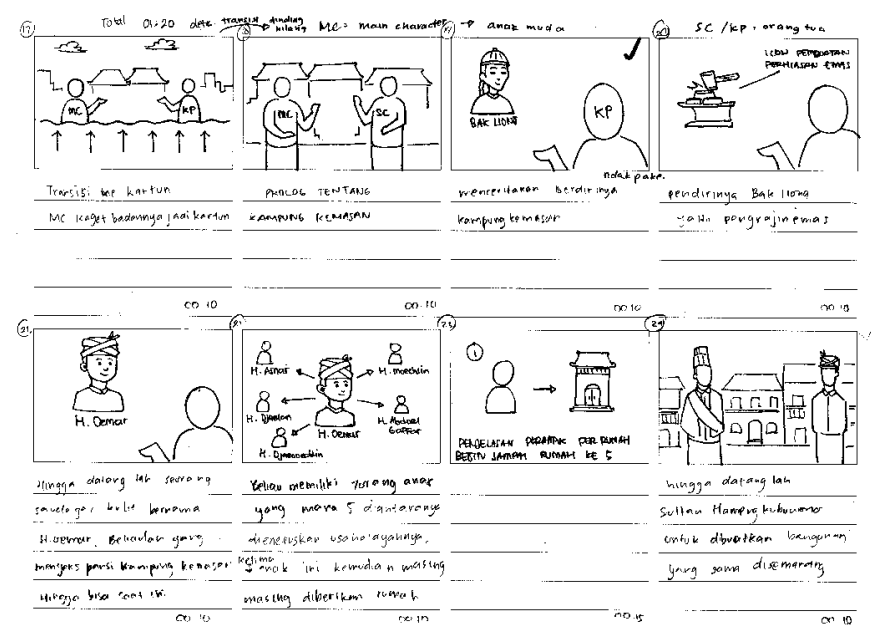

Gambar 8 Storyboard

Sumber : Firdhaus 2016

Untuk sinematografi, video edukasi ini meenggunakan sinematografi pendekatan gaya Giri Prasetyo, dengan mengarah kombinasi antara interaksi manusia, pengambilan suasana, dan landmark yang menjadi objek keseluruhan. Konsep itu dapat digunakan terhadap video ini, seperti interaksi manusia, bangunan landmark, dan suasana yang ada di Daerah Kota Tua Gresik.

Secara visual konten video akun disesuaikan dengan misalnya seperti :

1. Medium Close Up :

digunakan untuk memperlihatkan kegiatan pada jarak yang sedang, dengan detail pada objek tidak terlalu diperhatikan namun lebih ke kegiatan. Teknik ini sesuai dengan pengambilan gambar tentang interaksi manusia.

2. Close Up : digunakan untuk pengambilan objek gambar secara detail, teknik ini sesuai dengan pengambilan objek arsitektural bangunan, benda yang digunakan pada saat interaksi manusia,

3. Wide Angel Shot :

digunakan untuk mengambil objek gambar secara luas, tujuannya untuk bercerita kepada audiens tentang keadaan, atau bentuk utuh suatu bangunan.

Pengulangan sudut gambar pengambilan gambar menjadi acuan, karena untuk menceritakan suasana yang ada, kemudian mengambil gambar dengan jarak dekat, dengan tujuan untuk mengambil detail apa yang menjadi objek utama pada kejadian tersebut. Kemudian mengambil gambar dengan jarak yang agak jauh untuk mengetahui lokasi, waktu, dan suasan disekitar peristiwa tersebut. Begitu berulang.

Juga dibuat asset ilustrasi untuk animasi penunjang video edukasi ini. Ilustrasi ini menggambarkan peristiwa sejarah yang terjadi pada masa lampau, dengan menggunakan penggayaan pada masa kini.

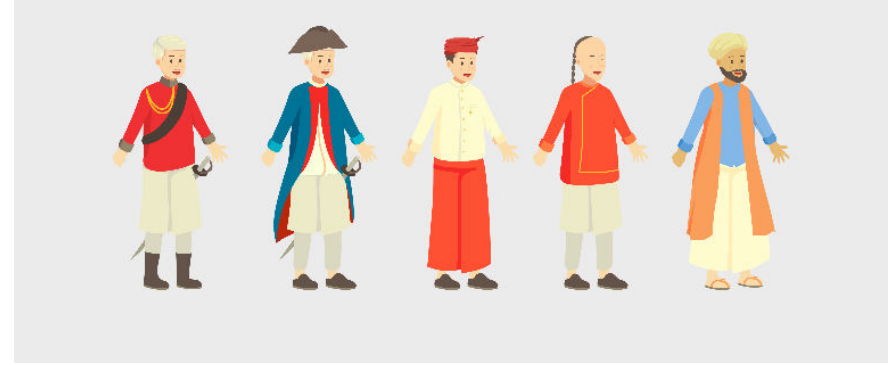

Gambar 9 Contoh ilustrasi manusia di Gresik pada abad 19 Sumber : Firdhaus 2016

\section{IMPLEMENTASI DESAIN}

Berikut adalah screenshoot beberapa adegan hasil implementasi konsep desain. Screenshoot yang diambil pada video real dan animasi. 

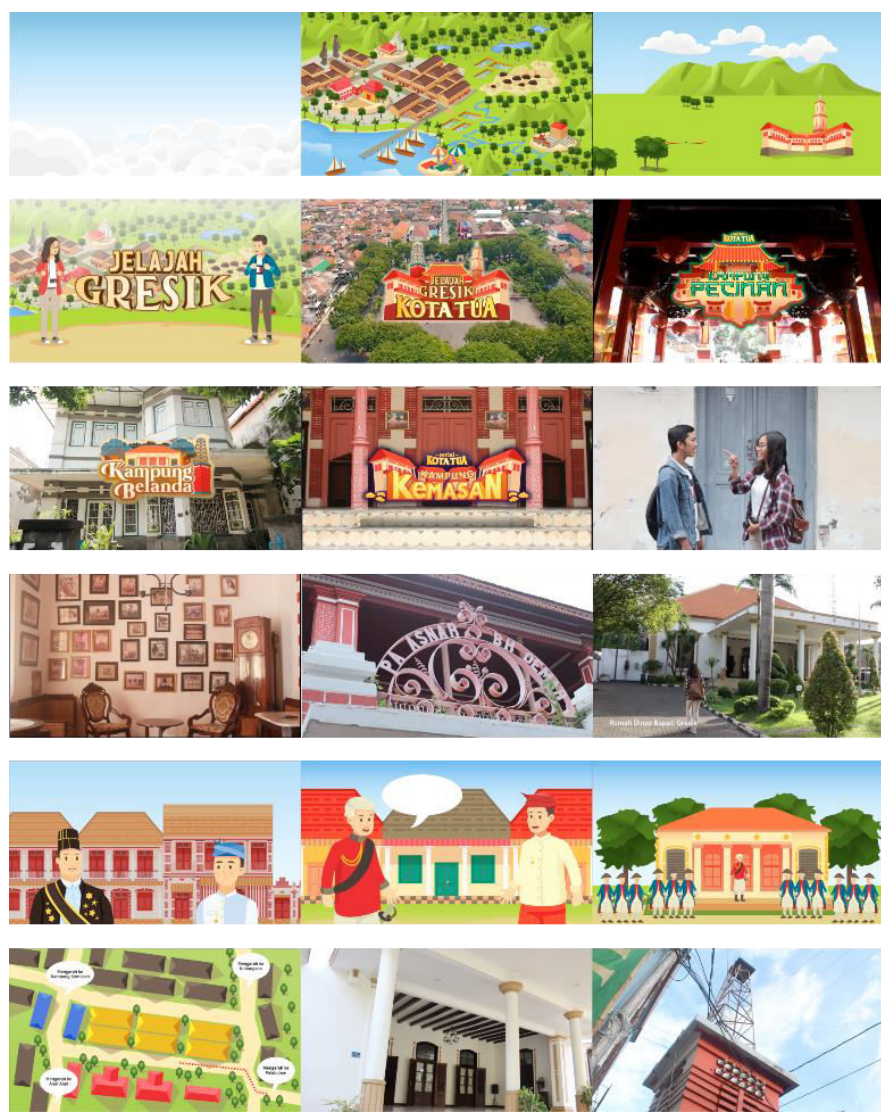

\section{KESIMPULAN/RINGKASAN}

\section{A. Kesimpulan}

Penilitian ini bertujuan untuk meningkatkan kesadaran sejarah Kota Tua Gresik pada masyarakat Gresik dengan menggunakan video edukasi. Berdasarkan analisis dan post test yang telah dilakukan, maka dapat dirumuskan kesimpulan, yaitu :

1. Hal yang dapat dilakukan untuk meningkatkan kesadaran sejarah pada tahap awal yaitu memahami kesejarahan yang disesuaikan dengan tingkat perkembangan, seperti datang ke museum, membaca buku / melihat video referensi tentang sejarah.

2. Dibutuhkan stimulant, seperti mengunjungi tempat bersejarah, dan bertemu dengan sejahrawan, untuk ke tingkatan kesadaran sejarah selanjutnya, yaitu berpikir secara kronologis terhadap sejarah.

3. Dampak dari tingginya tingkat kesadaran sejarah pada audiens yaitu adanya rasa memiliki pada sejarah yang ia ketahui, adanya perasaan bangga dan menjadi renungan terhadap sejarah yang ia ketahui.

4. Telah dilakukan post test terhadap audiens yaitu siswa SMA dengan status Cerdas Istimewa (CI). Adapun hasilnya : sebelum melihat video edukasi ini, hampir $90 \%$ siswa tidak mengetahui tentang sejarah dan peristiwa di Daerah Kota Tua Gresik.

5. Dari hasil post test, video ini dianggap berhasil karena audiens merasa bahwa mereka mendapatkan pengetahuan baru terhadap sejarah di Daerah Kota Tua Gresik dan dapat digunakan sebagai referensi.

\section{B. Saran}

Berhasilnya video edukasi tidak hanya dinilai dari konten yang dibuat dapat tersampaikan semua, namun juga dari aspek kontinuitas seri lain dan teknis dibalik layar pembuatan video. Maka penulis menyarankan untuk membahas topik lain seperti kebudayaan berupa seni tari, kriya dan musik. Juga mempertimbangkan variabel seperti pemilihan dan izin penilitiamn terhadap lokasi yang diteliti.

\section{UCAPAN TERIMA KASIH}

Penulis A.F. mengucapkan terima kasih kepada Dinas Pariwisata Kabupaten Gresik dan pihak pengelola dari tiap zona etnisitas yang telah memberikan kerja sama dengan kooperatif pada tahun $2016-2018$.

\section{DAFTAR PUSTAKA}

Dinas Pekerjaan Umum Kabupaten Gresik and Lembaga Penelitian dan Pengabdian kepada Masyarakat - ITS, "Studi Analisa Asset Bangunan Bersejarah di Kabupaten Gresik oleh Dinas Pekerjaan Umum Kabupaten Gresik dan Lembaga Penelitian dan Pengabdian kepada Masyarakat - ITS."

[2] O. Zainuddin, "Wawancara mendalam." 2016.

[3] Hamim, "Wawancara mendalam." 2016.

[4] T. Abdullah and A. Surjomihardjo, Ilmu Sejarah dan Historiografi (Arah dan Perspektif). Jakarta: Gramedia, 1984

[5] H. Kamarga, Alternatif Belajar Sejarah melalui e-learning Mengakses Sumber Informasi Kesejarahan. Jakarta: Inti Media, 2002.

[6] Anonymous, "Pengertian Media Audio Visual menurut Ahli," Globallavebookx.blogspot.co.id, 2015. [Online]. Available: http://globallavebookx.blogspot.co.id/2015/03/pengertian-mediaaudiovisual-menurut.html.

[7] I. Tarmarwan, "Pengenalan Audio Visual," Karya Visual Mandiri, $2015 . \quad$ [Online]. Available: http://www.karyavisualmandiri.com/category/wwwkaryavisualmandiri-com/. 